Отримано: 10 лютого 2019 р.

Прорецензовано: 25 лютого 2019 р.

Прийнято до друку: 1 березня 2019 p.

e-mail: lvtet@ukr.net

DOI: $10.25264 / 2519-2558-2019-5(73)-310-312$
Tetiana Cherepovska, Olena Binkevych. Morphological peculiarities of veterinary terminology in the context of teaching english for specific purposes. Наукові записки Національного університету «Острозька академія»: серія «Філологія». Острог: Вид-во НаУОА, 2019. Вип. 5(73), березень. С. 310-312.

\author{
УДК 81 '443 \\ Tetiana Cherepovska, \\ PhD, associate professor, Stepan Gzhytskyi National University of Veterinary Medicine and Biotechnologies Lviv \\ Olena Binkevych, \\ senior lecturer, Stepan Gzhytskyi National University of Veterinary Medicine and Biotechnologies Lviv
}

\title{
MORPHOLOGICAL PECULIARITIES OF VETERINARY TERMINOLOGY IN THE CONTEXT OF TEACHING ENGLISH FOR SPECIFIC PURPOSES
}

English for Veterinary Medicine, its main requirements and principles, are studied within the scope of English for Specific Purposes. The difference between the aims of the students studying ESP and those mastering it as a second language is demonstrated. The emphasis is made on the necessity of high competence in General English as a precondition for successful ESP work. The importance of the awareness of specific veterinary terminology, grammatical structures typical of scientific style and the ability to use them in communication in the future professional life is underlined. The article shows the peculiarities of veterinary terminological system and represents a typical classification of the given terms according to their structure. The main morphological features of the words of Greek and Latin origin are listed and analyzed in details. The importance of understanding the most frequently used terminoelements and their recognition in the structure of the unknown terms is shown. The phonetical peculiarities of some words are also demonstrated. The article comprises exercises for mastering and testing veterinary terminology in different reading, speaking, writing and listening activities. The complex attitude to such exercises as a preparation for future professional communicative activity is demonstrated. The necessity of using communicative approach is emphasized.

Key words: English for Specific Purposes; English for Veterinary Medicine; derivatives; structure; terminoelements.

\section{Череповська Тетяна Володимиівна, \\ кандидат філологічних наук, доиент \\ Бінкевич Олена Михайлівна,}

стариий викладач, Львівський національний університет ветеринарної медицини та біотехнологій імені С.3. Гљсицького

\section{МОРФОЛОГІЧНІ ОСОБЛИВОСТІ ВЕТЕРИНАРНОЇ ТЕРМІНОЛОГЇ̈ В КОНТЕКСТІ ВИКЛАДАННЯ АНГЛІЙСЬКОЇ МОВИ ЗА ПРОФЕСІЙНИМ СПРЯМУВАННЯМ}

Англійська мова для ветеринарної медицини трактується як така, щзо відповідає основним вимогам та принципам англійської мови за професійним спрямуванням. У статті розглядаються особливості ветеринарної термінологічної системи англійської мови та типова класифікація цих термінів відповідно до їхньої структури. Представлені основні морфологічні характеристики слів грецького та латинського походження, наголошена важливість їхнього розуміння для збагачення професійного мовлення. Стаття містить вправи для опанування ветеринарною термінологією. Підкреслюється необхідність комплексного підходу до роботи над професійними термінами та відпрацювання їх у всіх видах мовленнєвої діяльності. Продемонстровані деякі граматичні особливості наукового стилю ветеринарної літератури.

Ключові слова: англійська мова за професійним спрямуванням; англійська для ветеринарної медицин; деривативи; структура; терміноелементи

Introduction. The problem of English for Specific Purposes (ESP) methodology is very important nowadays. It was researched by many scholars, including L. Anthony, T. Hutchinson, A. Waters, S. Starfield. Comparing the needs of ESP students to those who study English as a Second Language (ESL), I. Potenko denotes that, unlike the last ones, they "are often mature people who already have some association with the language and are now learning it in more depth to use it in professional communication to achieve certain job-related functions" [8, p. 57]. According to Monica Bracaj, ESP learners "use language as a tool in facilitating success in professional life" [5, p. 42]. In order to help the students to achieve their goal, the teachers should employ "effective, ongoing, needs assessment and target situation analysis" [7, p. 118].

The mentioned above is equally true for the students and teachers of English in the domain of veterinary medicine. It requires both a high level of language competence in EGP (English for General Purposes) and mastering specific veterinary terminology and grammatical structures typical of scientific style. To achieve it, an emphasis is made on teaching professional terminology and practicing it in the complex of communicative activities.

Although "the teaching of vocabulary in ESP follows similar general principles to those in EGP" [6, p. 85], it is necessary to take into consideration the specific character of the terminology that is studied.

Thus, the aim of our work is to summarize the main features of veterinary terminology concerning its origin and structure and suggest the ways of practicing it in a complex of language activities. The methods of our research are the analysis of methodological literature and synthesis of theoretical data and practical experience. The communicative approach and partially the reading and grammar-translation methods are the basis of our work with students studying English for veterinary medicine. As the main idea of the communicative approach is to teach the learners to communicate in real-life situations, we choose the real texts as material for our classes based on modern investigations and rich in veterinary terms and content. We agree with O. S. Syrotin [4, p. 61], who states that the success in mastering special terminology depends on the right choice of the foreign professional material. We also create such exercises and tasks that encourage our students to speak more on the suggested topics and enable them to take part in the modelled conversations. 
Results and Discussions. Veterinary terms are very numerous and diverse. Following Yu. Rozhkov [3, p. 227], we understand them as special words denoting the notions of veterinary medicine as a science and a sphere of veterinary activity.

The origin of veterinary terms is mainly Greek or Latin. It is reflected in a number of derivative elements peculiar to them and inherited by modern European languages. Following V.V. Vynohradov, we regard such derivatives as international terminoelements [2, p. 164]. The most frequent examples of Greek prefixes and roots are: hypo- (e.g., hypothalamus), hyper- (hyperglycemia), -hydro(hydronephrosis), -aesth- (anaesthesia), -aem- (anaemia), -phyt- (phytotherapia), -pharm- (pharmacology). Latin prefixes and roots are duct- (e.g., ductal), -migr- (migration), sub- (subgastric), trans- (transmission) etc.

The origin of some terms is also reflected in their spelling and pronunciation. It is important to teach students to pronounce them correctly, e.g., -ch- is pronounced as [k] (e.g., bronchi, chemical, chimaera, chiropractic, cholesterol, chronic, hierarchy, ichthyology, stomach, technological), -ph- as [f] (eosinophilia, esophagus, lymph, nephritis, pharynx, phylum, prophylaxis), diphthong eu as [ju:], (pasteurization, pleuritic, leukocytosis), $\mathrm{p}$ is silent in words like pneumonia.

Plural of Greek and Latin nouns is also essential to take into consideration while teaching veterinary students: e.g., alveolus (sing) - alveoli (pl), bacillus (sing) - bacilli (pl), bacterium (sing) - bacteria (pl), diagnosis (sing) - diagnoses (pl), fungus (sing) fungi (pl), genus (sing) - genera (pl), nucleus (sing) - nuclei (pl), phylum (sing) - phyla (pl).

It is necessary not only to teach students some amount of professionalisms, but also to inform them of general peculiarities of English veterinary terms, including their structure, so that they could master them more successfully. Structurally, English veterinary terminology is multiform. I. Amelina and S. Hopak distinguish simple terms containing one word; complex ones comprising two words; combined forms; shortenings and abbreviations (containing one, two, three or four letters); derivative forms [1, p. 157].

The majority of medical and veterinary terms are derivative ones. The awareness of the unique morphology of veterinary terminology and its derivative elements (prefixes, roots, suffixes, and combining vowels) enables students to understand more words. The students should be taught to break such terms into prefixes, suffixes and roots, determine the meaning of the corresponding elements and make up definitions (e.g., CARDIO/LOGY: the study of the heart).

Prefixes usually indicate:

1) location (e.g., endo- means "within" or "inside": endoparasite is an organism that lives in the body; ecto- is "outside": ectoparasite is an organism that exists on the outer surface of the body; inter- stands for "between": intercostal - between the ribs);

2) number (poly-indicates excessiveness: polyuria is frequent urination; olygo- implies "little": oliguria is rare urination);

3) status (dis- means "painful" or "bad": dysphagia is difficulty while eating or swallowing);

4) time (post- is "after": postanaesthetic stands for "after anesthesia").

In order to practice the mentioned above groups of prefixes the following tasks could be suggested while working on veterinary terminology: 1) to look through common prefixes (e.g., a-/an-, ab-, ad-, anti-, ecto-, endo-, hyper-, hypo-, inter-, intra-, oligo-, peri-, poly-, post-, pre-, sub-, super-) and match them with their interpretations ("above", "after", "against", "around", "away from", "be-

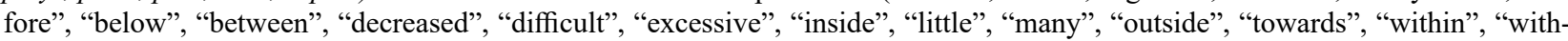
out"); 2) to find the opposites (ecto- / endo-, hyper-/ hypo-, pre- / post-, sub-/ super-); 3) to choose and fill in a prefix according to the given definition (...operative - pertaining to the period after operation (postoperative); ...natal - concerning the time before birth (prenatal)).

Roots are parts of the terms that hold the main meaning of the word. A great number of them concerns a corresponding organ or body system (e.g., arthr/o- ("joint"), cardi/o- ("heart"), cephal/o- ("head"), col/o- ("large intestine" ("colon")), derm- ("skin"), encephal/o- ("brain"), gastr/o- ("stomach"), hem/o ("blood"), hepat/o- ("liver"), hist/o- ("tissue"), nephr/o- ("kidney"), neur/o("nerve"), ophthalm/o- ("eye"), oste/o- ("bone"), rhin/o- ("nose"), ur/o- ("urinary tract").

To master the words with such roots, we offer our students different tasks. For example, three groups of words are given: 1) common root words (e..g., arthr/o, cardi/o, dent/o, enter/o, gastr/o, hepat/o, lapar/o, mast/o, nephr/o, naso/o, oste/o, rhin/o); 2) the words denoting the part of the body it relates to (abdomen, bone, heart, intestines, joint, kidney, liver, mammary gland, nose, stomach, teeth); 3) corresponding words and terminoelements in the native language. The tasks are: 1) to match the roots of the words from the first column with the words denoting the parts of the body from the second one; 2 ) to label the pictures of the body systems with the corresponding terms and 3 ) to memorize the pairs of words.

The next step is to teach the learners common medical (veterinary) suffixes with the following meanings: e.g., -itis (inflammation), -osis (condition), -ectomy (surgical removal), -stomy (making a surgical opening), -plasty (repairing surgically), -tomy (making an incision), - centesis (surgical puncture), -pathy (disease), -logy (the study of), -graphy (the act of using an instrument to record), -gram (a record of), -scope (instrument used to examine or view), -scopy (the act of using an instrument for viewing), -lysis (breaking down), -therapy (treatment). The tasks are: 1) to make up as many terms as the students can using common roots denoting mentioned above parts of the body and the suffixes (e.g., arthrosis, cardiogram, enteroscopy, gastrostomy, hepatitis, laparocentesis, mastopathy, nasotherapy, nephritis, osteopathy, rhinoplasty etc.); 2) to explain them in English and 3) to make up sentences with the new words. The work can be conducted in groups.

A number of memory techniques can be used for the retention of new terms: 1) a word tree;2) a diagram; 3) a matrix; 3) a bubble network, etc.

The following matrix could be used at this stage:

\begin{tabular}{|c|c|c|c|c|c|c|c|c|}
\hline & -plasty & -gram & -scopy & -stomy & -itis & -centesis & -pathy & -therapy \\
\hline \begin{tabular}{|l|} 
Cardio- \\
\end{tabular} & & + & & & & & & \\
\hline \begin{tabular}{|l|} 
Entero- \\
\end{tabular} & & & + & & & & & \\
\hline \begin{tabular}{|l|} 
Gastro- \\
\end{tabular} & & & & + & & & & \\
\hline Hepat- & & & & & + & & & \\
\hline \begin{tabular}{|l|} 
Laparo- \\
\end{tabular} & & & & & & + & & \\
\hline Masto- & & & & & & & + & \\
\hline \begin{tabular}{|l|} 
Naso- \\
\end{tabular} & & & & & & & & + \\
\hline Nephr- & & & & & + & & & \\
\hline \begin{tabular}{|l|} 
Osteo- \\
\end{tabular} & & & & & & & + & \\
\hline Rhino- & & & & & & & & \\
\hline
\end{tabular}


To test the terms, the following tasks are frequently used: 1) to fill in the blanks in the text with appropriate words; 2) to read definitions of the terms and guess a word. The students are also given 3) multiple choice and 4) true/false activities; 5) rearrangement tasks (e.g.: atitishep - hepatitis; pamastothy - mastopathy), etc..

Grammar at ESP classes doesn't take as much time as at ESL lessons but some aspects require our attention. Prepositions should be practiced throughout the course as they constitute some difficulty for the students, e.g., the task is to read the text "Bovine Tuberculosis" [9, p. 90-92] and fill in missing prepositions (e.g., to be caused_(by) bacteria, to be resistant_(to) heat, to pass_(through) the mucosa _ (with) fat globules, to be excreted _(into) the air etc.).

Irregular plural forms of some nouns concerning animals (e.g., a sheep - sheep, an ox-oxen, a fish - fish, a goose - geese, a mouse-mice, a deer-deer) are well known to the students from the course of ESL, but, nevertheless, should be mentioned as well as the collective nouns like cattle, swine, poultry, fowl, which are followed by verbs in plural, and the words ending in -s like surroundings, species, which are followed by verbs in singular.

Speaking on the veterinary scientific matters usually requires using the Passive Voice as it prevails in veterinary literature. The following activities are offered to practice it along with veterinary terms and correct word order: 1) to read the text and find examples of the Passive; 2) to write out all the Past Participle forms; 3 ) to turn the verbs (e.g., to inhale, to distribute, to cause, to characterize, to infect, to spread, to excrete, to contaminate etc.) into the Past Participle; 4) to put the words in the correct order (e.g., cannot/ cattle/grain/kept/be/alone/on - Cattle cannot be kept on grain alone); 5) to write the sentences in the Passive Voice (e.g., disease (to cause) by unknown bacteria. The virus (to carry) by insects. Several cows (to lose) because of improper care); 6) to make sentences in the Passive Voice active and vice versa.

The terms and grammar structures are practiced and tested in a complex of speaking, reading, writing and listening activities. For example, before studying the topic "Channels of Infection" [9, p. 89], the students are offered a brainstorm that consists in recollecting the names of the body systems. The next task is to read the text and write down all the diseases mentioned in the text and divide them into infectious and non-infectious ones. Then the following table could be offered to fill in after a detailed analysis of the text:

\begin{tabular}{|l|l|l|l|l|l|}
\hline $\begin{array}{c}\text { Channels } \\
\text { of infection }\end{array}$ & $\begin{array}{c}\text { The name of the } \\
\text { disease }\end{array}$ & $\begin{array}{c}\text { Infectious or non- } \\
\text { infectious one }\end{array}$ & $\begin{array}{c}\text { An affected body } \\
\text { system (in animals) }\end{array}$ & $\begin{array}{c}\text { Zoonosis } \\
\text { or not }\end{array}$ & $\begin{array}{c}\text { An affected body system } \\
\text { (in humans) }\end{array}$ \\
\hline $\begin{array}{l}\text { e.g., through } \\
\text { the alimentary } \\
\text { tract }\end{array}$ & Brucellosis & Infectious & Reproductive System & Zoonosis & $\begin{array}{l}\text { Nervous system, reproductive } \\
\text { system and joints }\end{array}$ \\
\hline
\end{tabular}

The students try to tell about the infections and their causation with the help of the given above table. As some information is not mentioned in the text (e.g., zoonosis character of some diseases and danger to people), the students have to listen to the additional information and fill it in the columns. They are also suggested some writing activities, e.g.: 1) to find the data about some other infections from electronic resources; 2) to fill in the table and make up sentences using the following Passive constructions: the disease is caused by...; the ... system is involved; the microorganisms are introduced into the organism with ...; the diseases can (cannot) be transmitted to people. The students share the information in groups and make up dialogues.

Conclusions. Teaching English for veterinary medicine, like any other branch of ESP, requires an insight into the peculiarities of its terminological system. Veterinary terminology is diverse in its origin and structure. Explaining the main morphological features of special terms as well as practicing them in a complex of various reading, writing, speaking and listening tasks provides required results in mastering scientific terminology and developing communicative skills needed for future professional activity.

\section{References:}

1. Амеліна С. М., Гопак I. М. Структурно-семантична характеристика англійських термінів підмови ветеринарії у контексті україномовного перекладу. Науковий вісник Національного університету біоресурсів і природокористування України. Серія: Філологічні науки. 2016. Вип. 248. С. 156-161.

2. Виноградов В. В. Основные типы лексических значений слова. Избранные труды. Лексикология и лексикография. Москва: Наука, 1977. С. $162-189$.

3. Рожков Ю. Г. Процеси запозичення в термінології ветеринарної медицини. Наукові записки Наиіонального університету «Острозька академія». Серія: Філологічна. 2016. Вип. 60. С. 227-229.

4. Сиротін О. С. Формування у студентів агробіологічних спеціальностей професійно-термінологічної компетентності засобами іноземної мови. Актуальні проблеми педагогіки, психології та професійної освіти. 2016. Том 2, № 2. С. 59-64.

5. Bracaj M. M. Teaching English for Specific Purposes and Teacher Training. European Scientific Journal. 2014. №10 (2). P. $40-49$.

6. Dudley-Evans T., St John M. J. Developments in English for Specific Purposes. A Multi-Disciplinary Approach. Cambridge: Cambridge University Press, 1998. $301 \mathrm{c}$.

7. Johns A. M., Salmani Nodoushan M. A. English for Specific Purposes: The State of Art (An online interview). International Journal Studies. 2015. № 9 (2). C. 113-120.

8. Potenko I. O. The communicative approach to teaching English for Specific Purposes. Науковий вісник Міжнародного гуманітарного університету. 2014. № 2 (24). С. 56-58.

\section{Illustrative material:}

9. Круглова Т. Н. Книга для чтения. Для студентов ветеринарных факультетов и институтов. Киев: Вища школа. 1983.175 с.

10. Farm Animal Diseases | Animal Welfare Information Center | NAL | USDA. URL: https: // www.nal.usda.gov.

11. Zoonotic Diseases \& Farm Animals. URL: https: // www.oregonvma.org. 